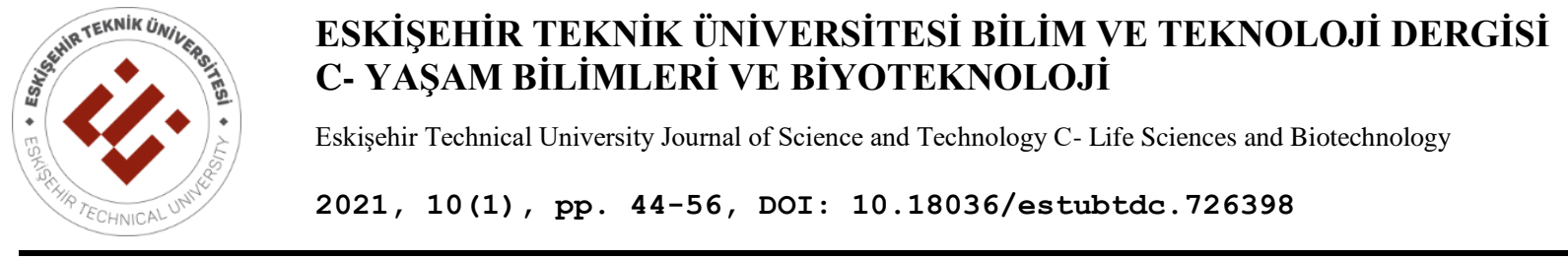

RESEARCH ARTICLE

\title{
LACCASE ISOLATION FROM SPENT MUSHROOM WASTE (AGARICUS BISPORUS): PARTIAL PURIFICATION, CHARACTERIZATION, IMMOBILIZATION AND BIOTECHNOLOGICAL APPLICATION
}

\author{
Güliz AK ${ }^{1,3}$ (iD) , Habibe YILMAZ ${ }^{2}$ (D) , Şenay HAMARAT ŞANLIER ${ }^{1,3}$, \\ ${ }^{1}$ Ege University, Faculty of Science, Biochemistry Department, Izmir, Turkey \\ ${ }^{2}$ Trakya University, Faculty of Pharmacy, Pharmaceutical Biotechnology Department, Edirne, Turkey \\ ${ }^{3}$ Ege University Research and Application Center of Drug Development and Pharmocokinetics, Izmir, Turkey
}

\begin{abstract}
Laccase was partially purified from mushroom compost with cheap and simple purification methods. Partially purified laccase was immobilized onto Amberlite XAD-7 resin. Immobilization conditions and textile dye (Direct Green B) decolorization of immobilized enzyme were examined. Laccase was partially purified from mushroom compost with 3.22 fold. Immobilization time for laccase was 30 minutes with $97 \%$ efficiency. The immobilization yield based on the activity was calculated by about $90 \%$. The immobilization yield was calculated as nearly $95 \%$ based on the measurement of protein amount at each stage. Immobilized enzyme preserved its initial activity with an $84 \%$ rate even after its tenth use. The free enzyme lost its activity immediately when it was incubated with the dye solution under its optimal conditions $\left(\mathrm{pH} 3.0\right.$ and $\left.65^{\circ} \mathrm{C}\right)$. On the contrary, the immobilized enzyme maintained its initial activity with a 53\% rate when incubated with dye solution under its optimal conditions $\left(\mathrm{pH} 3.5\right.$ and $\left.65^{\circ} \mathrm{C}\right)$.
\end{abstract}

Keywords: Mushroom compost, Laccase, Direct Green B, Diamine Green B, Enzyme immobilization, Dye decolorization, Amberlite XAD-7.

\section{INTRODUCTION}

Worldwide industrialization, urbanization, population growth and related environmental problems have been diminishing fertile agricultural areas day by day. In particular, for protein depleting and developing countries, there is a need for alternative nutrient sources. Produced culture fungi with high nutritional value without the need for soil and agricultural land is seen as the most effective nutrient to meet these needs [1].

The major cultivated mushroom species in the world trade, in general, are Agaricus spp, Agrocybe aegerita, Auricularia polytricha, Flammulina velutipes, Ganoderma lucidum, Grifola frondosa, Hericium Erinaceus, Lentinula edodes, Morchella spp., Pleurotus spp., Volvariella volvacea. Portobello mushroom is actually the mated state of Agaricus bisporus. This mushroom is commercially grown on pasteurized compost that contains straw waste, horse manure and wheat straw [2].

High amounts of mushrooms are produced worldwide every year. A large amount of waste mushroom compost is produced due to this production. On the other hand, these wastes, which will create environmental pollution if not used, are rich in valuable polymers, chitin, chitosan and proteins such as enzyme. Spent mushroom waste contains valuable enzymes such as cellulose, xylanase and laccase. Cellulase and xylanase are used for saccarification of biomass for biofuel production. Also, laccase have been used in decolorization of industrial dyes [3,4]. There are many studies ongoing about using laccase in bioremediation which contains the extraction, isolation and purification of the enzyme from multiple sources such as Pleurotus sapidus, Pleurotus ostreatus (PLO9), Ganoderma lucidum (GRM117),

*Corresponding Author: habibeyilmaz@trakya.edu.tr

Received: 24.04.2020 Published: 25.01.2021 
Phanerochaete chrysosporium strain ME 446 (ATCC 34541), Trametes versicolor strain CCBAS 614, Coriolopsis polyzona strain CCBAS 740, Pleurotus ostreatus strain 3004 and Irpex lacteus strain $617 / 93$ [5 - 7]. There are also dye decolorization studies with Agaricus bisporus species. However, there is no study on laccase extraction and purification from Agaricus bisporus wastes, immobilization to Amberlite XAD-7 resin and decolorization of Direct Green B with immobilized Agaricus bisporus laccase.

Laccase, a multi-copper containing enzyme, oxidizes different aromatic and non-aromatic compounds by using molecular oxygen with a radical-catalyzed reaction mechanism. The reduction of molecular oxygen to water provides catalysis of phenolic compounds by oxidation. Laccase enzymes are characterized by low substrate specificity and can oxidize a high variety of substrates such as diphenol, polyphenols, different substituted phenols, diamines, aromatic amines and even inorganic compounds such as iodine [8,9]. Laccase is an enzyme that has an increasing use in many industrial scales such as in delignification, dye decolorization, bioremediation, biofuel and ethanol production. Laccase production cannot be cheap and easy under the current conditions. There is a need for large amounts of laccase production for large-scale implementation to remedy of contaminated systems. The use of crude enzyme preparations can be expensive. To find the most effective laccase-producing supply, various studies are carried out such as the most suitable fungal type selection, reproducible and inexpensive methods of isolation, in terms of optimizing enzyme production conditions [10].

Laccase is useful in dye decolorization studies, however, using crude enzyme has some disadvantages such as thermostability and susceptibility to inhibitors. Also, the crude enzyme can be used once. On the other hand, the immobilization process can enhance its stability and can allow its repeated usage which is economically more favorable [11].

Due to the chemical structures of dyes, they are light, water and fade resistant. Moreover, most of them are synthetic based chemicals consequently it is difficult to decolorize these dyes. However, the removal of dyes from industrial wastes for environmental reasons is required. The development of methods based on laccase seems to be a suitable solution that has a potential for the decomposition of various synthetic dyes including constantly used dyes in the textile industry [12].

Immobilized enzymes were the hearth of innovative biotechnological processes as alternatives to traditional chemical technologies. They offer different advantages such as; the high catalytic activity, specificity and selectivity, production in large amounts and economic viability. Industrial application of laccases requires efficient methods to immobilize the enzyme, yielding a biocatalyst with high activity and stability compared to free enzyme. Due to economic considerations, applications of laccases on an industrial scale requires immobilization and also reusability. Immobilization would also facilitate a continuous process. Despite the laccase is widely used for dye removal, it is known from the literature that laccase can easily lose its activity due to its low thermal and $\mathrm{pH}$ stability and it can be inactivated by inhibitors in wastewater. Therefore, the routine use of free laccase for dye decolorization is limited.

In this study, waste mushroom compost which was obtained after harvest of mushroom production used as a laccase source and this laccase immobilized onto Amberlite XAD-7 resin for biotechnological purpose. After the optimization of immobilization conditions, reaction conditions and stability tests of immobilized enzyme was performed and compared with the free enzyme. The immobilized laccase and the free laccase were investigated for possible use in decolorization of Direct Green B / Diamine Green $\mathrm{B}$ which is a widely used textile dye. Amberlite XAD-7 resin is a polyacrylic acid ester polymer which has a hydrophilic surface and mild polarity. This resin was chosen for laccase immobilization based on its high adsorption capacity.

Here we report, an easy method for immobilization of laccase onto a commercially available and high capacity resin for dye decolorization purpose. Because the resin is commercially available and 
abundance of laccase along with the ease of the preparation method, the system has high applicability in industrial waste waters. According to the literature study conducted, to the best of our knowledge, no studies on immobilization and dye removal of the laccase to Amberlite XAD-7 resin have been found.

\section{MATERIALS AND METHODS}

\subsection{Materials}

Waste mushroom compost as a laccase source in dried form was a kind gift from Prof. Dr. İhsan Yaşa who is a lecturer at E.U. Faculty of Science Microbiology Department. Amberlite XAD-7 and ABTS (2,2'-azino-di-3-ethyl-benzo-thiazolin-sulphonate) were purchased from Sigma. All the other reagents used in this study are in the analytical grade. Structure of Direct Green B /Diamine Green B can be seen in Figure 1.<smiles>Nc1c(/N=N/c2ccc([N+](=O)[O-])cc2)c(S(=O)(=O)[O-])cc2cc(S(=O)(=O)[O-])c(N=Nc3ccc(-c4ccc(NNc5ccc(O)cc5)cc4)cc3)c(O)c12</smiles>

Figure 1. Chemical Structure of Direct Green B (CAS No: 4335-09-5).

\subsection{Partial Purification of Laccase from Waste Mushroom Compost}

$10 \mathrm{mg}$ mushroom compost was suspended in $100 \mathrm{~mL}$ distilled water for 30 minutes at room temperature. Protein and activity analyses were performed at this solution. $80 \%$ ammonium sulfate precipitation was done and centrifuged at $6000 \mathrm{rpm}$ for 20 minutes at $+4^{\circ} \mathrm{C}$. The upper phase of the centrifuged sample was analyzed for protein and activity determination and pellet was dissolved in $5 \mathrm{~mL}$ distilled water. The dissolved pellet was dialyzed (12000 MW) against distilled water for over a night. After protein and activity analyses were done, ultrafiltration $(30 \mathrm{kDa})$ was performed on dialysate. The protein amount and activity of the upper and lower phases of ultrafiltrate were investigated. Purification fold rates between partial purification stages were calculated by the proportion of mushroom compost activity to the purified phase of the samples.

Protein determination was performed by using the Bradford method [13]. Enzyme activity was estimated spectrophotometrically by using ABTS as a substrate as earlier reported [14]. While calculating the free and immobilized enzyme activity the following equation was used.

$$
\operatorname{Activity}(\mathrm{U} / \mathrm{ml})=\frac{\Delta A}{36000 M^{-1} \mathrm{~cm}^{-1}} \times \frac{3}{1000} \times 10^{6} \times \frac{1}{t(\min )} \times \frac{1}{V_{\text {enzyme }(\mathrm{mL})}}
$$

\subsection{Immobilization of laccase to Amberlite XAD-7}

\subsubsection{Determination of optimal immobilization time}

Enzyme containing acetate buffer ( $\mathrm{pH}$ 4.0) was added to $200 \mathrm{mg}$ Amberlite XAD-7 resin and left for incubation on an orbital shaker $(240 \mathrm{rpm})$ at room temperature. In order to estimate optimum immobilization time, protein content was analyzed at a range between 10-120 minutes and immobilization yield was calculated. 


\subsection{2. pH effect on immobilization efficiency}

For the purpose of defining the $\mathrm{pH}$ effect on immobilization efficiency, enzyme immobilization was done by using various buffer solutions with $\mathrm{pH}$ ranging from 2.0 to 8.0 (pH 2.0 and 3.0 glycine buffer; pH 3.0-6.0 acetate buffer, $\mathrm{pH}$ 6.0-8.0 phosphate buffer). After incubation at optimum time, protein content was analyzed at each sample's upper phases.

\subsubsection{Effect of enzyme amount on immobilization efficiency}

In order to determine enzyme amount on immobilization efficiency, enzyme solutions with varying concentrations (enzyme amount varied between 0.63-12.64 mg-protein) were added onto $20 \mathrm{mg}$ Amberlite XAD-7 resin and immobilization assay was performed at optimal conditions. After operation, activity and protein amount analyses were achieved at each phase of sample and immobilization efficiency was calculated.

\subsection{Immobilization of Partially Purified Laccase onto Amberlite XAD-7 Resin and Calculation of Immobilization Yield}

Large quantities of partially purified laccase were immobilized on the carrier under optimum conditions and in order to determine the optimum operating conditions, the immobilized enzyme was stocked. To this end, enzyme immobilization was achieved by adding the enzyme to $300 \mathrm{mg}$ of the carrier under stirring at $240 \mathrm{rpm}$ for 30 minutes at room temperature. Protein and activity of the upper phase were determined. In order to determine the loss of activity during the immobilization, activity assays were performed in the lower phase. Then the lower phase was lyophilized to determine if there is a loss of activity during lyophilization.

\subsection{Characterization of immobilized laccase}

Activities of $5 \mathrm{mg}$ immobilized laccase was measured by using acetate buffer with different $\mathrm{pH}$ 's which was in a range of 3.0 to 6.0. Also, activities of the free enzyme were measured at the same conditions and the optimal $\mathrm{pH}$ of both free and immobilized enzymes was established. After determining the optimum $\mathrm{pH}$, by measuring the activities between $25-75^{\circ} \mathrm{C}$ at standard conditions optimal temperature values of both free and immobilized enzymes were calculated.

\subsection{Stability tests of free and immobilized enzymes}

In order to determine storage stability of the free and immobilized enzyme, partially purified enzyme in distilled water and dried form of immobilized enzyme was stored at $-20^{\circ} \mathrm{C}$ and activities of both enzymes were measured at predetermined time intervals, then the loss of activity ratio was calculated by comparing with the values of the initial activity.

In order to determine the loss of activity at optimum $\mathrm{pH}$ and temperature, free and immobilized enzyme samples were incubated at predetermined time intervals and enzyme activity was measured at standard conditions for comparison with initial activity.

\subsection{Process Stability of Immobilized Enzyme}

After the measurement of immobilized enzyme activity at stated standard conditions, the immobilized enzyme was washed three times with buffer solution $(5 \mathrm{~mL}, \mathrm{pH} 3.5)$ and activity measurements were performed in repetition. Each measurement was performed again after the washing process and values of the relative activity of the immobilized enzyme process were established by repeating the washing process for 10 times. \% residual activity calculated. 


\subsection{Determination of Direct Green B, Usage of the free and immobilized enzyme for Direct Green B dye decolorization}

In order to determine the removed dye amount at later studies, spectrum scan was performed to estimate the wavelength and standard curve was constructed.

The free and immobilized enzyme which have same activities were added to $50 \mathrm{~mL}$ Direct Green B textile dye solution $(0.1 \mathrm{mg} / \mathrm{mL}$ at optimum $\mathrm{pH}$ and temperature) under constant shaking rate and dye concentrations were measured in samples taken at predetermined time intervals to calculate dye decolorization yield at each sample. As a control, $50 \mathrm{mg}$ Amberlite XAD-7 resin was treated at the same conditions as the immobilized enzyme to estimate the adsorbed dye amount by the resin.

\section{RESULTS AND DISCUSSION}

\subsection{Partial Purification of Laccase from Waste Mushroom Compost}

The determination of protein content was achieved by using standard deviation which was $\mathrm{y}=2.1142 \mathrm{x}$ with 0.986 correlation. In partial isolation study of laccase, in each step, samples were taken and protein amount and enzyme activity were determined. Protein concentrations, volumetric activities, specific activities, total activities and purification folds of each sample were defined and shown in Table 1.

Table 1. Activities and Purification Folds of Partial Isolated Laccase

\begin{tabular}{|c|c|c|c|c|c|c|c|}
\hline $\begin{array}{c}\text { Purification } \\
\text { Steps }\end{array}$ & $\begin{array}{c}\text { Protein } \\
\text { concentration } \\
(\mathbf{m g} / \mathbf{m L})\end{array}$ & $\begin{array}{c}\text { Volumetric } \\
\text { Activity } \\
(\mathbf{U} / \mathbf{m L})\end{array}$ & $\begin{array}{c}\text { Specific } \\
\text { Activity } \\
(\mathbf{U} / \mathbf{m g})\end{array}$ & $\begin{array}{c}\text { Total } \\
\text { Activity } \\
(\mathbf{U})\end{array}$ & $\begin{array}{c}\text { Purification } \\
\text { Fold }\end{array}$ & $\begin{array}{c}\text { Volume } \\
(\mathbf{m L})\end{array}$ & $\begin{array}{c}\text { Yield } \\
(\%)\end{array}$ \\
\hline $\begin{array}{c}\text { Mushroom } \\
\text { Compost }\end{array}$ & 7.93 & 2.64 & 0.333 & 134.6 & 1.0 & 51 & 100 \\
\hline $\begin{array}{c}\text { (NH4)2SO4 } \\
\text { Precipitation } \\
\text { Upper Phase }\end{array}$ & 0.24 & - & - & - & - & - & - \\
\hline Dialysate & 19.89 & 21.16 & 1.064 & 169.3 & 3.20 & 8 & 39.3 \\
\hline $\begin{array}{c}\text { Ultrafiltrate } \\
\text { Lower Phase }\end{array}$ & 0.34 & - & - & - & - & - & - \\
\hline Ultrafiltrate & 89.72 & 96.16 & 1.072 & 211.6 & 3.22 & 2.2 & 48.8 \\
\hline
\end{tabular}

Partial purification process started with extraction and isolation of laccase from mushroom compost. Obtained extract then subjected to ammonium sulfate precipitation and followed with the centrifugation process. No activity was expected to remain at the upper phase and anticipated to remain at the pellet. Likewise, at the ultrafiltration step, it is expected to present smaller molecular weighted proteins at the lower phase and no activity as well as remain of all activity at ultrafiltrate. As can be seen in Table 1, no activity was observed at the centrifugate and ultrafiltrate phases. Obtained data showed that partial purification was achieved successfully. The whole process yielded with 3.22 fold (partial) purification of laccase from mushroom compost. Researchers are using different ways for the extraction or isolation of laccase from their sources. Lim et al. used tap water, distilled water, $\mathrm{pH} 4.5$ sodium citrate buffer and pH 7.0 sodium phosphate buffer in order to monitor the extraction buffer effect on enzyme activity. They simply mixed the spent mushroom compost with buffers and incubated at varying time intervals at $4{ }^{\circ} \mathrm{C}$ and $20^{\circ} \mathrm{C}$ followed by filtration via miracloth (pore size 22 to $25 \mu \mathrm{m}$ ) and centrifugation. Their best result was $2.2 \pm 0.30 \mathrm{U} / \mathrm{g}$ with $\mathrm{pH} 4.5$ sodium citrate buffer [4]. On the other hand, we achieved to higher activity by using salting-in technique and ultrafiltration. 


\subsection{Immobilization of laccase to Amberlite XAD-7}

\subsubsection{Determination of optimal immobilization time}

Determination of time parameter at the immobilization stage is important for the necessity to estimate the immobilization efficiency with varying time periods as well as saving time in terms of economy.

As seen in Figure 2, the immobilization yield reached to $95 \%$ at a short span like ten minutes, immobilization yield increased to $97 \%$ at $30 \mathrm{~min}$ and fixed at this yield after this time. Therefore, the optimal time was chosen as 30 minutes for enzyme immobilization. Pezella et al. immobilized laccase mixture on Perlite and evaluated experimental conditions on immobilization yield. They employed 3 different times as $1 \mathrm{~h}, 4 \mathrm{~h}$ and overnight immobilization. Their best immobilization yield was $70 \%$ at room temperature (RT), $\mathrm{pH} 6.5$ and $1 \mathrm{~h}$ [15]. Compared to their studies we reached 97\% immobilization yield in $30 \mathrm{~min}$. at $\mathrm{pH} 3$ at room temperature.

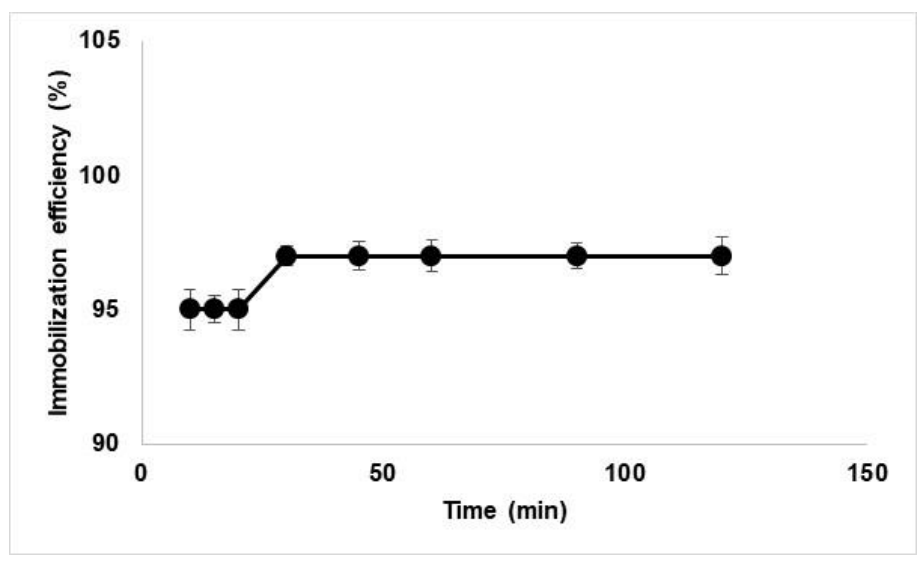

Figure 2. Effect of time on immobilization efficiency (pH 4.0 acetate buffer, RT)

\subsection{2. pH effect on immobilization efficiency}

It is an important step to determine the $\mathrm{pH}$ value where the resin and enzyme interaction is maximum during laccase immobilization to determine immobilization efficiency. Changing $\mathrm{pH}$ value is a key element in affecting the immobilization efficiency due to affecting of both enzyme and resin from the $\mathrm{pH}$ of the equilibrium. The effect of $\mathrm{pH}$ on immobilization efficiency was shown in Figure 3.

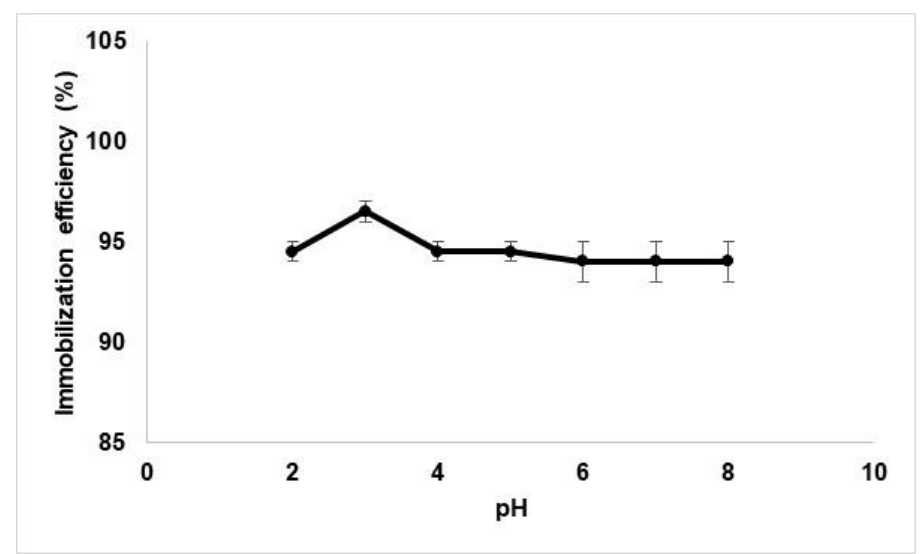

Figure 3. Effect of pH on immobilization efficiency (30 min., RT) 
Based on the obtained data, change in $\mathrm{pH}$ value does not affect immobilization efficiency. Because Amberlite XAD-7 resin does not contain ionizable residues. It is a nonionic macro reticular resin that adsorbs and releases ionic species through hydrophobic and polar interactions. Therefore, immobilization achieved with non-covalent interactions (through hydrophobic and polar interactions) instead of ionic interactions.

\subsubsection{Effect of enzyme amount on immobilization efficiencş}

During the immobilization process, the usage of excess enzyme that the resin able to bind can cause the loss of enzyme from carrier surface of the resin as well as it can cause additional cost due to the usage of more enzyme than the resin able to carry. Therefore, it is necessary to determine the maximum amount of enzyme that can bind on the carrier. The obtained data resulted from the experiment was shown in Figure 4.

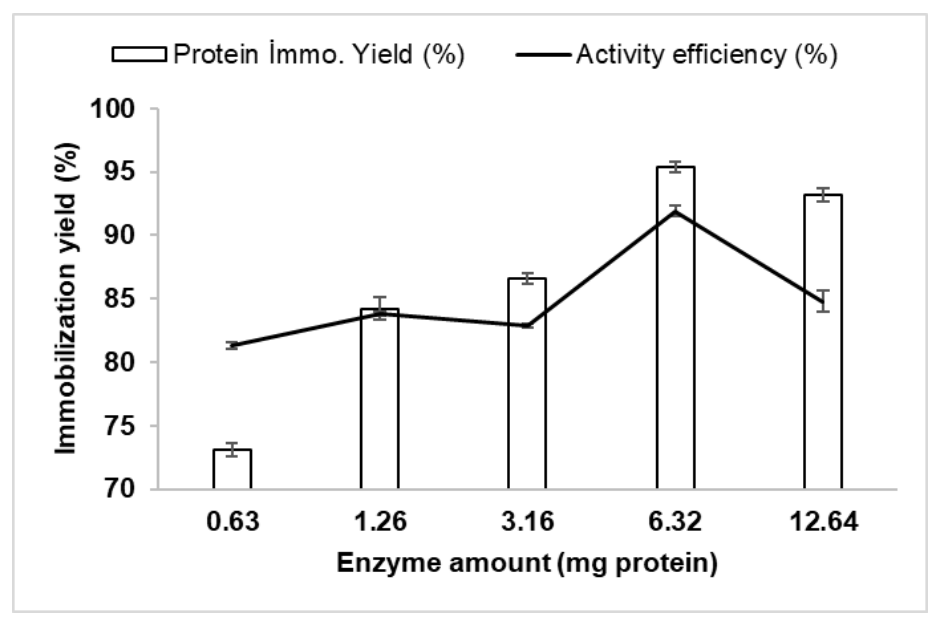

Figure 4. Enzyme amount effect determined both by protein immobilization efficiency and activity yield $(\mathrm{pH} 3.0$ acetate buffer, RT, $30 \mathrm{~min}$.).

As can be seen in Figure 4, the appropriate enzyme amount was found as $6.32 \mathrm{mg}$-protein $(6.77 \mathrm{U})$ experimentally and determined as the optimum value. Liu et al. immobilized laccase onto carbon-based mesoporous magnetic composites via adsorption. Their adsorption capacity was $491.7 \mathrm{mg} / \mathrm{g}$ whereas we immobilized $632 \mathrm{mg} / \mathrm{g}$ laccase onto Amberlite-XAD 7 resin [16]. Compared to Liu et al. study, our choice of immobilization support yielded better results.

\subsection{Immobilization of Partially Purified Laccase onto Amberlite XAD-7 Resin and Calculation of Immobilization Yield}

Immobilization of laccase by performing optimal immobilization conditions was done and immobilization yield was calculated by measuring the activity and protein amount on the upper phase and washing waters after immobilization. The free enzyme which was added to equilibrium in order to immobilize onto resin had $782.5 \mathrm{U}$ total activity while upper phase and washing waters after immobilization had $78.25 \mathrm{U}$ total activity. Basis of enzyme activity put into the equilibrium, the immobilization yield based on the activity was calculated by about $90.0 \%$. The immobilization yield was calculated as nearly $95.0 \%$ based on the measurement of protein amount at each stage. As can be seen in Figure 4, there is a $5.0 \%$ loss of enzyme activity when compared to during the immobilization process.

\subsection{Characterization of Immobilized Laccase}

By measuring the enzyme activities in different buffer solutions that have different $\mathrm{pH}$ values, $\%$ relative activity values were established under standard conditions. We performed a study that was not published yet and used laccase that purified from Spent mushroom waste and in another study we performed, it 
was found the optimum $\mathrm{pH}$ value as 3.0 for laccase. In this study, we determined the optimal $\mathrm{pH}$ value as 3.5 for the immobilized enzyme (Figure 5). A large decrease was observed in the activity of the immobilized enzyme above $\mathrm{pH} 3.5$. There was not a very big variance for $\mathrm{pH}$ value when compared to the free enzyme. Fungal laccases have isoelectric point ranged $\mathrm{pH}$ 3.0-7.0. In our study, we estimated this value as 3.0. As Madhavi, V. and Lele, S.S stated earlier in their studies, laccase's optimal pH is highly dependent on its substrate and optimal $\mathrm{pH}$ value can vary. This variation may be due to the changes in the reaction caused by substrate, oxygen or enzyme itself. As known, laccase is an oxidative enzyme that contains three copper ions. First copper (C1) ion interacts with water and copper 2 (C2) and 3 (C3) interacts with each other and substrate at enzyme's active site which has an important role in catalysis. The redox potential differentiation between the substrate and first copper ion can increase oxidation at high $\mathrm{pH}$ values. On the other hand, increased $\mathrm{OH}$ ions can disrupt the internal electron transfer between $\mathrm{C} 1$ and $\mathrm{C} 2 / \mathrm{C} 3$ which concluded with enzyme inhibition. The dramatic decrease in activity between $\mathrm{pH} 3.0$ to $\mathrm{pH} 4.0$ may depend on the increased $\mathrm{OH}^{-}$ions in equilibrium which leads the enzyme inhibition. Furthermore, the constant enzyme activity supports the idea of lost enzyme activity due to the presence of $\mathrm{OH}^{-}$ions [10].

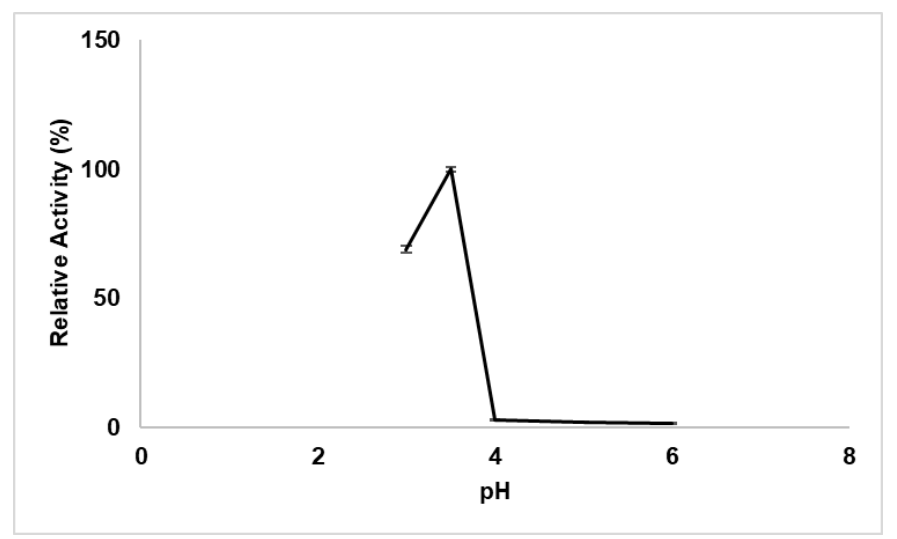

Figure 5. Immobilized enzyme behavior at different $\mathrm{pH}$ values (30 min., RT)

Immobilized enzyme activities in different temperatures which were measured by using optimum buffer solution ( $\mathrm{pH} 3.5$ ) can be seen in Figure 6. The optimal temperature is known as $65^{\circ} \mathrm{C}$ for the free enzyme that purified from mushroom compost. In our study, as can be seen from Figure 6, the optimum temperature for the immobilized enzyme was not changed compared to the free enzyme and was found as $65^{\circ} \mathrm{C}$. Lassouane et al. found that both free and immobilized laccases showed optimal activity at $40^{\circ} \mathrm{C}$. Beyond this temperature, the activity loss observed in their study. At $70^{\circ} \mathrm{C}$, entrapped and crosslinkedentrapped laccases showed $49.1 \%$ and $54.6 \%$ relative activity, respectively [17]. Compared to their immobilization study in terms of optimal temperature, our immobilization strategy gave better results.

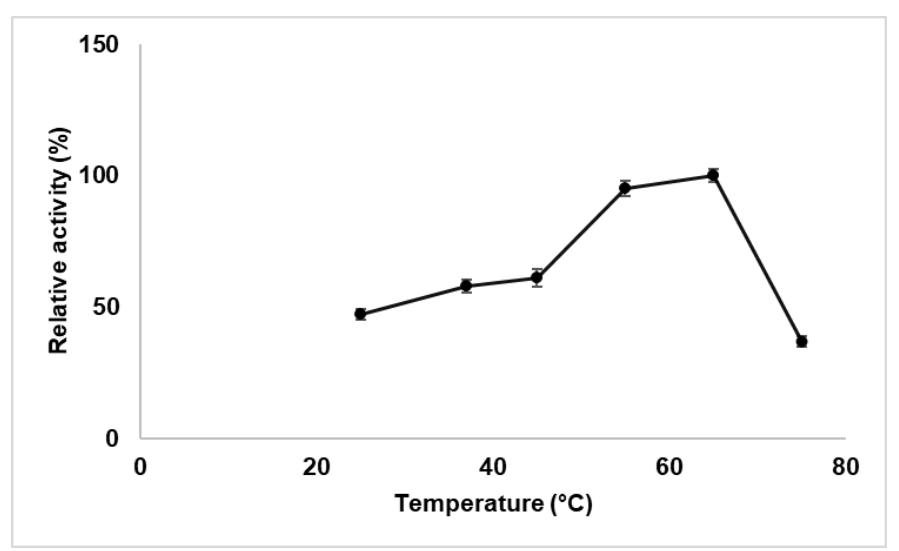

Figure 6. Optimal temperature estimation for the immobilized enzyme (pH 3.5 acetate buffer, 30 min.) 


\subsection{Stability Tests of Free and Immobilized Enzymes}

Stability tests were performed both for the free and immobilized enzyme at optimal activity conditions. For this purpose, the free enzyme was incubated in $\mathrm{pH} 3.0$ buffer solution at $65^{\circ} \mathrm{C}$ and at predetermined time intervals enzyme activity was monitored by adding ABTS as a substrate. Similar to the free enzyme, immobilized enzyme was incubated in $\mathrm{pH} 3.5$ buffer solution at $65^{\circ} \mathrm{C}$ and at predetermined time intervals enzyme activity was monitored by adding ABTS as a substrate in standard conditions. The stability test results at optimal conditions for free and immobilized enzyme can be seen in Figure 7.

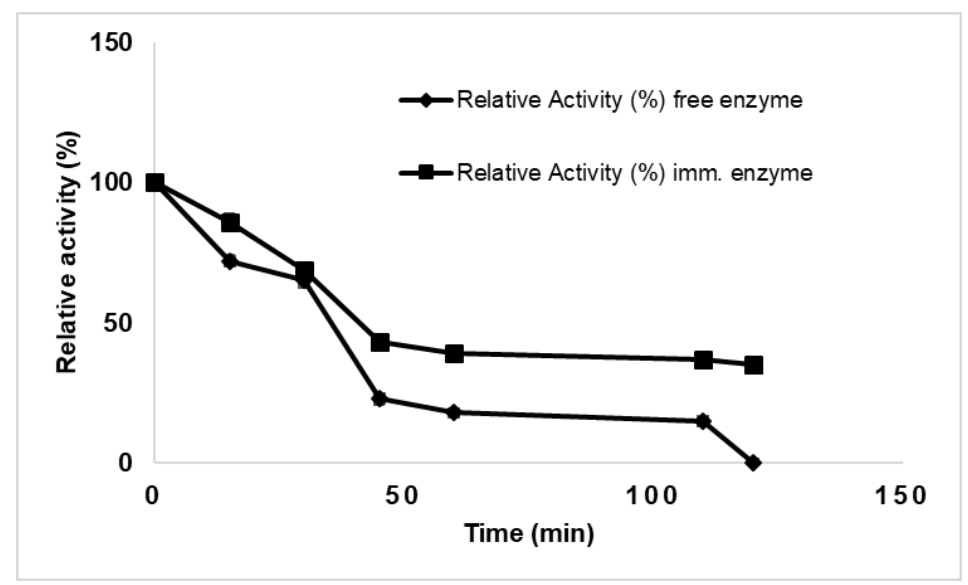

Figure 7. Stability test results at optimal conditions for the free and immobilized enzyme (pH 3.5 acetate buffer, $\left.65^{\circ} \mathrm{C}\right)$.

The difference between enzyme activity of free and immobilized laccase may depend on the conservation of enzyme in the immobilization process. It is thought that at $65^{\circ} \mathrm{C}$ temperature, the free enzyme is more open to structural decomposition then immobilized laccase. Therefore, higher activity loss observed in the course of time for the free enzyme. On the other hand, the immobilized enzyme is adsorbed onto the resin with hydrophobic and polar interactions and to lose its activity, hydrophobic and polar interactions may be broken first. Herewith, the activity loss may occur a little sooner than the free enzyme.

\subsection{Process Stability of Immobilized Enzyme}

After activity measurement of the immobilized enzyme, the immobilized enzyme washed three times with $\mathrm{pH} 3.5$ buffer solution and activity measurements performed ten times in order to determine residual enzyme activity. As seen in Figure 8, the immobilized enzyme maintained its initial activity of $84.0 \%$. The loss of $16.0 \%$ activity may depend on the leakage of the enzyme from the resin because the enzyme did not immobilize covalently to the resin. But as we can see from the whole process and stability results, this activity loss is not significantly higher and the process is very cheap and useful for industrial applications. This result indicated that the immobilized enzyme has process stability for reusage. Xu et al. covalently immobilized laccase onto PVA/CS/MWNTs and PVA/CS for drug removal from wastewater. When they examined the operational (process stability) stability of immobilized enzyme was more stable at $10^{\text {th }}$ operation compared to free enzyme. The process stability of immobilized enzyme was nearly $84 \%$ for Immobilized laccase-PVA/SC and $89 \%$ for Immobilized laccasePVA/SC/MWNTs. Even we did not use covalent immobilization, we had similar results with their study [18]. 


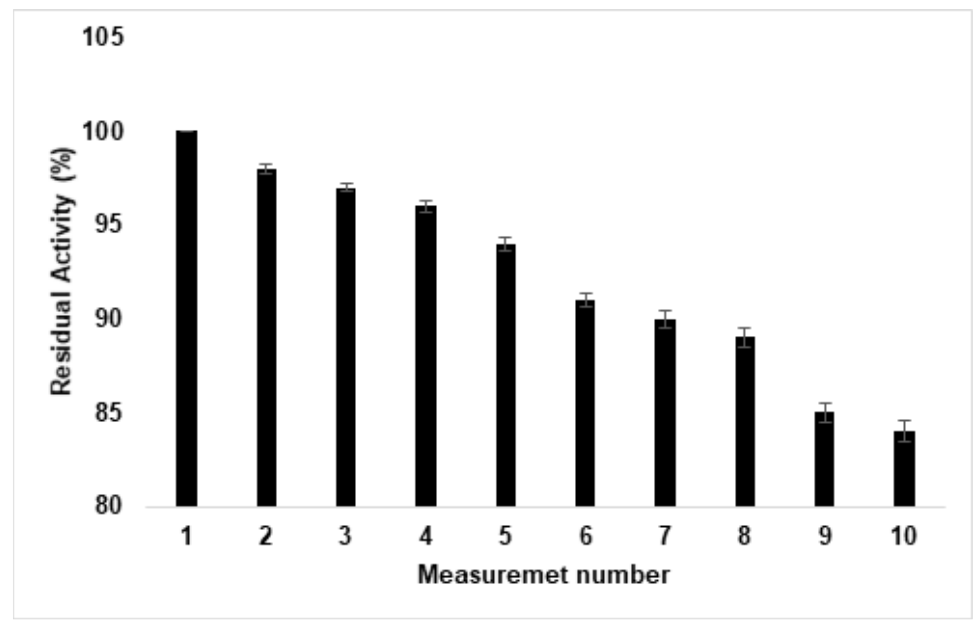

Figure 8. Process stability of immobilized enzyme (pH 3.5 acetate buffer, RT)

When studies in the literature are reviewed; in a study performed by Wong et al., laccase was immobilized with alginate/gelatin beads that contain PEG and the beads were cross-linked with glutaraldehyde. The beads containing laccase which were prepared under optimum conditions were used to remove the Red B-3BF textile dye. It was stated that beads maintained its initial activity with a 50\% rate after tenth use [19].

\subsection{Determination of Direct Green B, Usage of the Free And Immobilized Enzyme for Direct Green B Dye Decolorization}

In order to analyze Direct Green B decolorization capacity of the enzyme, wavelength scan of dye were studied. Wavelength scan showed that the maximum absorption occurred at $631 \mathrm{~nm}$ wavelength. The calibration curve was constructed for Direct Green B in $0.01 \mathrm{mg} / \mathrm{mL}$ to $0.1 \mathrm{mg} / \mathrm{mL}$ concentration range and obtained equation was $y=8,4103 x$. This equation was used at later studies for calculation of dye decolorization yield.

The immobilized and free enzyme that has the same activity rate $(1 \mathrm{U} / \mathrm{mg})$ was added to $50 \mathrm{~mL}$ optimal buffer solution which contains $0.1 \mathrm{mg} / \mathrm{mL}$ Direct Green B textile dye at a constant shaking rate. Samples were taken and measured at predetermined time intervals to determine dye decolorization yield. It was detected from three times repetition of the experiment that free enzyme was inhibited in the dye solution and has no activity (Data not shown). On the contrary, the immobilized enzyme was not inhibited in the dye solution and maintained its activity which has resulted in dye decolorization. As a control, the same amount of Amberlite XAD-7 resin with immobilized enzyme was added to $50 \mathrm{~mL}$ of $\mathrm{pH} 3.5$ citrate buffer in the same conditions and incubated to estimate the adsorbed dye amount of resin. At the end of the time period, Amberlite XAD-7 resin showed a 19.0\% dye decolorization yield (data not shown). The dye decolorization yield of immobilized enzyme was shown in Figure 9. Dye decolorization yield of the immobilized enzyme at 180 . min was $53.0 \%$. 


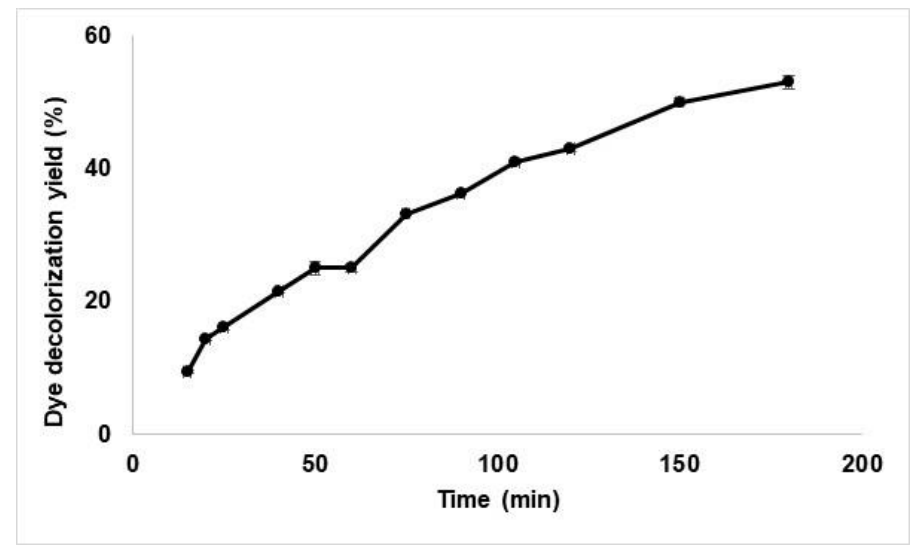

Figure 9. Direct Green B decolorization efficiency of the immobilized laccase (pH 3.5 acetate buffer, RT).

In a study of Bayramoglu and coworkers performed, they immobilized Trametes Versicolor laccase by applying the graft-polymerization process to magnetic spheres with poly (4-vinyl pyridine), poly (VP) new metal-chelating polymers. Laccase immobilized within metal connected magnetic spheres was used to remove Reactive Green 19, Reactive Red 2 and Reactive Brown 10 textile dyes. They stated that after 6 hours after dye decolorization studies at batch system, dye decolorization efficiency was $38 \%, 51 \%$ and 59\% for Reactive Green 19, Reactive Red 2 and Reactive Brown 10, respectively [20]. In another study that Cristovao and coworkers reported, laccase immobilization was carried out by using green coconut fibers. Dye decolorization efficiencies of this study were $40 \%, 48 \%, 23 \%, 4 \%, 7 \%$ and $0 \%$ for Reactive Blue 114, Reactive Yellow 15, Reactive Black 5, Reactive Yellow 176, Reactive Red 180 and Reactive Red 239, respectively. Dye decolorization efficiencies were \%90, \%93, \%90, \%0, \%93, \%96 respectively, when mediator was used. The study also observed increased thermal stability for immobilized enzyme compared to the free enzyme. In their study, while the free enzyme was inactivated in 5 minutes at $60^{\circ} \mathrm{C}$, immobilized enzyme was inactivated in 1 hour. From the operational stability of the immobilized laccase, $30 \%$ activity loss can be observed after 5 times usage and $45 \%$ activity loss can be observed after 13 times usage [21].

Azo dyes such as Direct Green B possess one or more azo group in their structure. There are several physicochemical methods for their decolorization such as adsorption, chemical treatment, ion pair extractions. However enzymatic decolorization and degradation can be achieved by azoreductases and laccases [22]. Based on the literature data, laccases catalyze oxidation of phenolic ring by one electron to produce phenoxy radical followed by another oxidation to generate carbonium ion which is localized on the phenolic ring carbon bearing the azo linkage. Then, nucleophilic attack by water produces 4sulfophenyldiazene and a benzoquinone. 4-sulfophenyldiazene oxidized to corresponding phenyldiazene radical which loses its molecular nitrogen and produce sulfophenyl radical. This radical then scavenged by oxygen and yields 4-sulfophenylhydroperoxide (SPH) [23].

\section{CONCLUSION}

At the present time, azo dyes such as Direct Green B (Diamine Green B) are frequently used in the textile industry. All conventional methods used in dye decolorization from wastewaters have high capital costs, implementation difficulties and a large amount of waste. Therefore, in order to lower the costs and increase the efficiency of decolorization, the commercial use of laccase studies carried out in recent years.

Laccase is an extracellular enzyme that belongs to polyphenol oxidase group enzymes that contain copper and using molecular oxygen as the electron acceptor to catalyze the oxidation of various phenolic compounds. Laccase used in many studies as pulping, dye removal, bioremediation, ethanol production and biosensors due to its broad substrate specificity. Commercially produced free laccase routinely used 
in many industrial organizations. Spent mushroom waste laccase that we used in our study is not commercially produced and there is no literature on isolation and immobilization of this laccase.

Despite the laccase is widely used for dye removal, it is known from the literature that laccase can easily lose its activity due to its low thermal and $\mathrm{pH}$ stability and it can be inactivated by inhibitors in wastewater. Therefore, the routine use of free laccase for dye decolorization is limited. In our wotk, we partially purified the laccase with 3.22 fold yield by using simple purification procedures (ammonium sulfate precipitation-centrifugation-dialysis-ultrafiltration-lyophilization) from a waste which is Spent mushroom waste. Obtained laccase was used to prepare immobilized enzyme which has higher storage stability, operation stability and process stability by using cheap enzyme immobilization techniques. Immobilized enzyme preserved its initial activity with an $84.4 \%$ rate even after its tenth use. The free enzyme lost its activity immediately when it was incubated with the dye solution under its optimal conditions ( $\mathrm{pH} 3.0$ and $65^{\circ} \mathrm{C}$ ). On the contrary, the immobilized enzyme maintained its initial activity with a $53.0 \%$ rate when incubated with dye solution under its optimal conditions $\left(\mathrm{pH} 3.5\right.$ and $\left.65^{\circ} \mathrm{C}\right)$. When the activity loss of the immobilized enzyme was taken into account at this temperature and $\mathrm{pH}$ conditions, the experiment was stopped at 180 minutes. When laccase used in commercial processes, mediators should be used with the enzyme. However, there was no need for mediators to remove dye from equilibrium. On the other hand, it is thought that the mediator usage with our immobilized enzyme can positively influence dye decolorization and dye can be removed in a shorter time span with higher activity. Thus, by shortening the incubation time under optimal conditions it can be possible to prevent inhibition.

In this study, an immobilized enzyme preparation was formulated that allows to use many times for dye decolorization even in non-mediator containing equilibrium compared to literature findings.

\section{ACKNOWLEDGMENT}

The authors acknowledge to Prof. Dr. İhsan YASA for gifting the mushroom compost. The authors have declared no conflict of interest.

\section{REFERENCES}

[1] Chang ST \& Miles PG. A New Look at Cultivated Mushrooms. Bioscience. 1984; 34(6): 358-362.

[2] Phillips R \& Reid DR. Mushrooms, UK. London: Pan Macmillan Limited, 2006.

[3] Alhulajaily A, Yu H, Zhang X, Ma F. Highly Efficient and Sustainable Spent Mushroom Waste Adsorbent Based on Surfactant Modification for the Removal of Toxic Dyes. Int. J. Environ. Res. Public Health. 2018; 15: 1421-1436.

[4] Lim SH, Lee YH, Kang HW. Efficient Recovery of Lignocellulolytic Enzymes of Spent Mushroom Compost from Oyster Mushrooms, Pleurotus spp., and Potential Use in Dye Decolorization. Mycobiology. 2013; 41(4): 214-220.

[5] Bilal $\mathrm{M}$ and Asgher M. Biodegradation of agrowastes by lignocellulolytic activity of an oyster mushroom, Pleurotus sapidus. J. Natn. Sci. Foundation Sri Lanka. 2016; 44(4): 399-407.

[6] Oliveira SF, Rodrigues da Luz JM, Kasuya MCM, Ladeira LO, Junior AC. Enzymatic extract containing lignin peroxidase immobilized on carbon nanotubes: Potential biocatalyst in dye decolourization. Saudi J. Biol. Sci.. 2018; 25(4): 651-659.

[7] Machado KMG and Matheus DR. Biodegradation of remazol brilliant blue $\mathrm{R}$ by ligninolytic enzymatic complex produced by Pleurotus ostreatus. Braz. J. Microbiol. 2006; 37(4): 468-473. 
[8] Mayer AM \& Staples RC. Laccase: new functions for an old enzyme. Phytochemistry. 2002; 60(6): 551-565.

[9] Claus H. Laccases: structure, reactions, distribution. Micron. 2004; 35(1-2): 93-96.

[10] Madhavi, V \& Lele SS. Laccase: Properties and applications. BioResources, 2009; 4(4), 16941717.

[11] Chhabra M, Mishra S, Sreekrishnan TR. Immobilized laccase mediated dye decolorization and transformation pathway of azo dye acid red 27. J Environ Health Sci Eng. 2015; 13(38): 1-9.

[12] Couto SR \& Toca-Herrera JL. Lacasses in the textile industry. Biotechnol. Mol. Biol. Rev. 2006; 1(4): 115-120.

[13] Bradford MM. A rapid and sensitive method for the quantitation of microgram quantities of protein utilizing the principle of protein-dye binding. Anal. Biochem. 1976; 72: 248-254.

[14] Hamarat Sanlier Ş, Gider S, Köprülü S. Immobilization of laccase for biotechnology applications. Artif. Cells Nanomed. Biotechnol. 2012; 41(4): 259-263.

[15] Pezella C, Russo ME, Marzocchella A, Salatino P, Sannia G. Immobilization of a Pleurotus ostreatus Laccase Mixture on Perlite and Its Application to Dye Decolourisation. Biomed Res. Int. 2014: 308613.

[16] Liu Y, Zeng Z, Zeng G, Tang L, Pang Y, Li Z, Liu C, Lei X, Wu M, Ren P, Liu Z, Chen M, Xie G. Immobilization of Laccase on Magnetic Bimodal Mesoporous Carbon and the Application in the Removal of Phenolic Compounds. Bioresour. Technol. 2012; 115: 21-26.

[17] Lassouane F, Aït-Amar H, Amrani S, Rodriguez-Couto S. A promising laccase immobilization approach for Bisphenol A removal from aqueous solutions. Bioresour. Technol. 2019; 271: 360-367.

[18] Xu R, Tang R, Zhou Q, Li F, Zhang B. Enhancement of catalytic activity of immobilized laccase for diclofenac biodegradation by carbon nanotubes. Chem Eng J. 2015; 262: 88-95.

[19] Wong P, Fan X, Cui L, Wong Q, Zhan A. Decolorization of reactive dyes by laccase immobilized in alginate/gelatin blent with PEG. J. Environ. Sc1-Chına. 2008; 20: 1519-1522.

[20] Bayramoglu G, Yilmaz M, Arica YM. Reversible immobilization of laccase to poly(4vinylpyridine) grafted and $\mathrm{Cu}(\mathrm{II})$ chelated magnetic beads: Biodegradation of reactive dyes. Bioresour. Technol. 2010; 101: 6615-6621.

[21] Cristovao RO, Tavares APM, Brigida AI, Loureiro JM, Boaventura RAR, Macedo EA, Coelho MAZ. Immobilization of commercial laccase onto green coconut fiber by adsorption and its application for reactive textile dyes degradation. J. Mol. Catal., B Enzym. 2011; 72: 6-12.

[22] Singh RL, Singh PK, Singh RP. Enzymatic Decolorization And Degradation Of Azo Dyes - A Review. Int. Biodeterior. Biodegradation. 2015; 104: 21-31.

[23] Chacko JT, Subramaniam K. Enzymatic Degradation Of Azo Dyes - A Review. Int. J. Environ. Sci. 2011; 1(6): 1250-1260. 